\title{
THE THEME SYSTEM AND BYZANTINE PROVINCIAL ARMED FORCES AT THE EARLY PALAEOLOGIAN PERIOD (1259-1328)
}

\author{
Vladimir A. Zolotovskiy \\ Volgograd State University, Volgograd, Russian Federation
}

\begin{abstract}
Introduction. The purpose of the paper is to reveal the state, nature and the leadership system of stratiotic forces as part of the Byzantine provincial armed forces of the Early Palaeologian period. The paper aims to determine the methods of organizing Byzantine provincial armed forces in the context of the characteristic of the early Palaeologian armed forces and the institute of pronoia. The author defines the military-strategic, social and economic characteristics of the stratiotic military service. Methods. Critical use of elements of civilizational, formational and systemic approaches is the methodological basis of this study. It should be noted that the system approach is used to determine the specificity of the relationships within all essential structural elements of the military organization. It also makes it possible to identify the factors of its modernization in connection with social and state processes. It allows to reveal the functional features of the military organization elements. Analysis and Results. The analysis of act materials and narrative sources shows a clear social difference of soldiers-stratiotes from the rest of the empire's population, including proniares. The author determines that the sources contain information about all economic institutions that characterize stratiotes in their traditional, early byzantine military-technical definition. The statements of Byzantine historians about the participation of stratiotes in military actions clearly indicate the preservation of the military-administrative function of "theme organization". Act materials do not contain information about a specific number of stratiotes. This makes it difficult to determine the total number of stratiotic formations. However, the participation of stratiotic detachments in almost all military operations of the Byzantine army is a well-known fact. Narratives indicate their number. All this makes it possible to draw a reasonable conclusion about the preservation of stratiotic armed forces and the traditional system of their recruitment.
\end{abstract}

Key words: History of Byzantium, Early Palaeologian period, military organization, stratiotes, proniares.

Citation. Zolotovskiy V.A. The Theme System and Byzantine Provincial Armed Forces at the Early Palaeologian Period (1259-1328). Vestnik Volgogradskogo gosudarstvennogo universiteta. Seriya 4. Istoriya. Regionovedenie. Mezhdunarodnye otnosheniya [Science Journal of Volgograd State University. History. Area Studies. International Relations], 2019, vol. 24, no. 6, pp. 231-244. (in Russian). DOI: https://doi.org/10.15688/jvolsu4.2019.6.18

УДК 94 «13/15»: 341.321 .3

Дата поступления статьи: 01.02.2019

ББК 63.3(0)4-93

Дата принятия статьи: 18.07.2019

\section{ФЕМНАЯ СИСТЕМА И ПРОВИНЦИАЛЬНЫЕ ВООРУЖЕННЫЕ СИЛЫ ВИЗАНТИИ РАННЕПАЛЕОЛОГОВСКОГО ПЕРИОДА (1259-1328 Гг.)}

\section{Владимир Алексеевич Золотовский}

Волгоградский государственный университет, г. Волгоград, Российская Федерация

\footnotetext{
Аннотация. В рамках исследования раскрыты роль провинциальных вооруженных сил в военной организации Византии и специфика состояния фемной организации в раннепалеологовский период. Анализ актовых материалов и данных нарративных источников показывает четкое социальное отличие воинов-стратиотов от остального населения империи, включая прониаров, а также особое обозначение их положения в документах. В ходе исследования нами было установлено, что источники содержат упоминания всех экономических институтов, характеризующих стратиотов в их традиционном ранневизантийском значении. Кроме того, сообщения византийских историков об участии в военных действиях воинов-стратиотов явно указывают на сохранение военно-административных функций фемной организации. Отсутствие данных о конкретной численности стратиотов в официальных источниках не позволяет точно определить общую численность формирований и, соответственно, выявить соотношение стратиотского войска с прониарским
} 
и наемным, а также установить его роль в военной организации Византии. Вместе с тем участие стратиотских отрядов практически во всех военных операциях византийской армии, а также частные упоминания об их многочисленности в нарративных источниках позволяют со всей обоснованностью сделать вывод о сохранении стратиотского войска и традиционной системы комплектования. Действовавшие стратиотские формирования обеспечивали функционирование фортификационной системы и сдерживали наступление противника до прибытия императорского войска.

Ключевые слова: история Византии, раннепалеологовский период, военная организация, стратиоты, прониары.

Цитирование. Золотовский В. А. Фемная система и провинциальные вооруженные силы Византии раннепалеологовского периода (1259-1328 гг.) // Вестник Волгоградского государственного университета. Серия 4, История. Регионоведение. Международные отношения. - 2019. - Т. 24, № 6. - С. 231-244. - DOI: https://doi.org/10.15688/jvolsu4.2019.6.18

Введение. Военная история Византии привлекала внимание исследователей на протяжении столетий. Однако вопрос о специфике военной организации, проблема принципов формирования и боевых функций отдельных частей вооруженных сил империи позднего периода стали предметом специальных исследований лишь в последние десятилетия. При этом можно говорить о закреплении в византиноведении ряда общепринятых представлений. В частности, утверждается, что су-

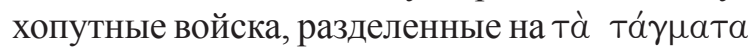
и та̀ Ө́́ната [30, р. 243-245, 249-251; 14, p. 183-184; 1, с. 59], находились под командованием великого доместика [30, р. 237-238, $242 ; 28$, р. 353, 367, 368] и его заместителя протостратора [30, р. 240-241]. Вместе с тем отдельные вопросы так и не получили должного внимания в научной литературе. Наиболее дискуссионно в историографии представлена проблема структуры провинциального войска никейского и палеологовского периодов.

Цель статьи - охарактеризовать состояние, природу и механизм управления стратиотскими формированиями в составе провинциальных вооруженных сил Византии раннепалеологовского периода. С учетом специфики источниковой базы, фактически лишенной полемологической составляющей, достижение цели представляется возможным, прежде всего, посредством выделения квалифицирующих характеристик «классических» стратиотских формирований в поздневизантийской военной организации. В связи с этим последовательно будут раскрыты следующие вопросы: служба и статус стратиотов, состав и численность провинциального войска, структуры фемного войска.
Методы. Методологической основой работы является критическое использование элементов системного, цивилизационного и формационного подходов. Применение системного подхода в совокупности исследовательского инструментария, используемого при анализе военной организации, позволяет определить специфику взаимосвязи всех ее сущностных структурных совокупностей, выявить факторы и направление ее модернизации в связи с социальными и государственными процессами, раскрыть функциональные особенности элементов военной организации. Кроме того, именно системный анализ позволяет выбрать наиболее объективный подход к изучению проблемы развития и функционирования военной организации, а также роли каждого из системообразующих военных институтов.

Отдельные направления тематического исследования военного дела и вооруженных сил могут быть продуктивны при использовании базовых методологических установок структурализма. Они позволят углубить проблематику изыскания посредством анализа стратегем, военно-научных концепций и институтов военной организации в срезе специфики раннепалеологовского времени.

Анализ. В современном византиноведении по вопросу стратиотской службы отдано предпочтение концепции, согласно которой стратиотские формирования были заменены на прониарские силы. П. Каранис одним из первых ассоциировал прониарскую службу с поздним этапом эволюции стратиотской [17, p. 131].

Эта идея, в разрезе теории феодализации поздней Византии Г. Острогорского, была воспринята и переработана Л. Максимовичем. 
Стремясь институционализировать систему управления палеологовской империи, исследователь пришел к выводу о ее децентрализации, нашедшей выражение в том числе в ликвидации фемной системы [6, с. 109].

Фактор феодализации в эволюции военной организации, выраженный в переходе от стратиотских (крестьянских) к прониарским (феодальным) ополчениям, был развит в последующей литературе. При этом, по мнению некоторых исследователей, армия была переведена на прониарскую феодальную основу $[9$, с. 119], а категории стратиотов и акритов упразднены [9, с. 117-118; 8, с. 104-105]. Другие же акцентировали внимание на развитии в империи больших коллективных и малых проний, представлявших последнюю эволюционную форму стратиотской службы [28, p. 367, 368].

Наиболее системно эта концепция была изложена в ряде работ М. Бартусиса. В своих изысканиях американский ученый прошел долгий путь. Его начало связано с базовыми выводами о тождественности стратиотов и прониаров, обоснованными гипотезой об идентичности пронии и икономии [13, р. 347]. Работая с простагмой Михаила Палеолога, ученый пришел к выводу о том, что солдатам, проявившим в боях доблесть, по решению Михаила VIII и Андроника II разрешалось пожалование пронии с посотис от 24 до 36 перперов [12, S. 270-271].

Как и Л. Максимович, М. Бартусис признавал за фемами палеологовской империи лишь фискальные и гражданско-административные функции. При этом военные функции фем, связанные с комплектованием и обеспечением армии, американский ученый отнес к военному квазифемному образованию - великой аллагии [14, p. 194-195, 202]. Продолжая идею Л. Максимовича, историк предложил концепцию военно-иерархической структуры управления великой аллагией: 1) кефалий управлял гражданским населением крепости в военных целях; 2) кастрофилакс контролировал работу по обеспечению военных интересов города; 3) командование прониарским войском великой аллагии осуществлял чауш [14, р. 197]. Обобщая результаты исследования, М. Бартусис склонился к пониманию великой аллагии как единственной институционально органи- зационной форме поздневизантийской армии [14, p. 204].

В последующих работах исследователь лишь усиливал собственные выводы: источники позднего периода сообщают о категориях военнослужащих исключительно в значении прониаров [15, p. 2-11]; упоминаемая в источниках стратия являлась рядовой повинностью крестьян [15, p. 5, 6]; статус стратиотов был тождественен прониарскому [16, р. 164-169, 182-184, 186]; стратиотские списки палеологовского периода являлись списками прониаров [16, р. 238-239].

В заключение историографического обзора отметим, что изложенная выше концепция получила широкую поддержку в современной литературе. Так, И. Караянопулос, основываясь на известных данных и положениях работ Н. Икономидиса и М. Бартусиса, повторил предположение о замене стратиотской службы прониарской. Кроме того, исследователь поддержал мнение об объеме посотис пронии и икономии [33, б. 21-23], а также о роли и характеристике великой аллагии [33, б.28-32]. В обобщающей работе С. Кириакидиса также воспроизводится эта идея как основная [24, p. 216]. Учитывая наработки Н. Икономидеса, Э. Арвейлер и М. Бартусиса, автор так же и в этом же направлении раскрыл содержание и значение великой аллагии [24, p. 82-93].

\section{Характеристика службы и статус стратиотов}

Данные используемых нами актовых и нарративных материалов XIII-XIV вв. позволяют предположить, что воины-страти-

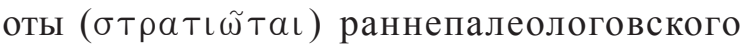

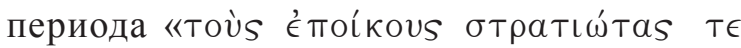

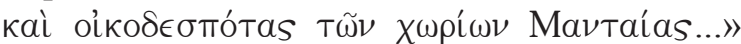

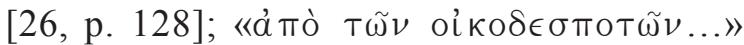

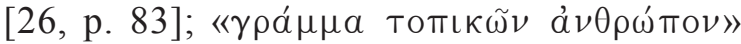

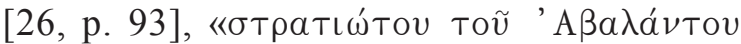

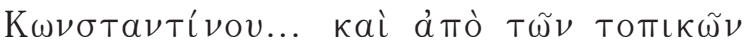

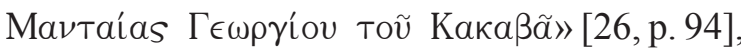

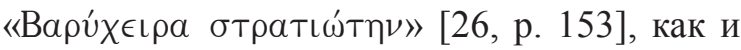
прежде [31, p. $286^{19}$ ], отличались от остального сельского населения империи (о̊кобе́бтотац,

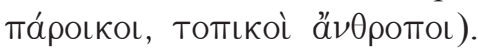

Одним из фундаментальных признаков особого статуса воинов-стратиотов являлось юридическое положение земель, находив- 
шихся в их владении. Согласно известной по законодательству средневизантийской эпохи юридической практике земли передавались на праве possessio под обеспечение выполнения воинской обязанности. Таким образом, факт передачи земли в воинское владение символизировал переход получателя в статус стратиота.

Специальный правовой статус воинских земель отражался в их особом наименовании:

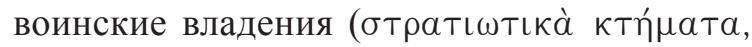

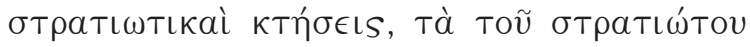
ákí $\eta т \alpha)$; земли, выданные за воинскую службу (oi тп̃s бтратєías тóтоь); владения или управления за исполнение воинской службы

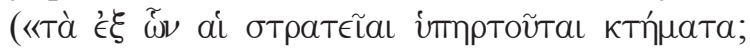

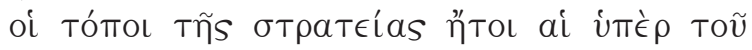

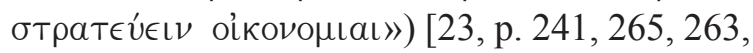

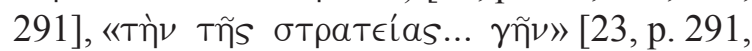
266]). Вполне очевидно, что произошедшие в поздний период изменения в социально-экономических отношениях привели к замене традиционных терминов на более характерные для обозначения функции управления - икономия (оікороні́a [29, vol. I, p. $293^{4}$, vol. III, p. $175^{27}$, $\left.285^{25-26}\right]$ ) и прония (тро́vola [22, vol. 2, p. $58^{21}$, $63^{15}$; 29, vol. I, p. $31^{16}, 51^{12}, 81^{11}, 131^{19} ; 29$, vol. I, p. $557^{26}$; 29, vol. IV, p. $425^{15-16 ;} 32$, p. $286^{21}$ ]).

Система обеспечения воинов-стратиотов, основанная на наделении их земельными участками, закрепилась в публичной практике еще в период расцвета фемной организации. При этом с целью сохранения боеспособности был установлен минимальный размер владения для конных воинов и воинов имперского флота ${ }^{1}$. Опираясь на данные сборника Арменопула, можно предположить, что форма обеспечения воинов-стратиотов земельными владениями сохранилась и в

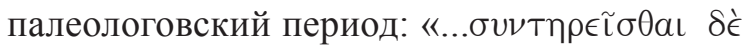

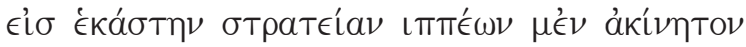

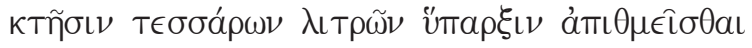

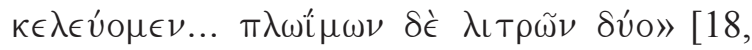
$\S 7$, p. $\left.180^{1-3}\right]$.

Следует пояснить, что размер стоимости земель определялся объемом дохода от их обработки. Именно в связи с этим в источниках стратиотская служба связывается с получением дохода от самостоятельной обработки или от взимания части дохода:

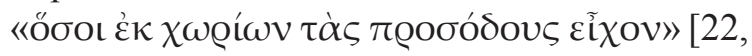

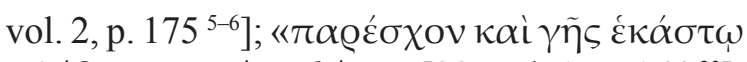
$\pi \lambda \dot{\varepsilon} \theta \varrho \alpha \chi \varrho \cup \sigma i ́ \omega \nu \delta \varepsilon ́ \kappa \alpha »\left[22\right.$, vol. 1, p. $\left.164{ }^{23}\right]$. Таким образом, «получение годового дохода от земли» определенно подчеркивает связь специального социально-экономического статуса стратиотов с земледелием. Кроме того, такие формулировки конкретизируют отличие статуса воина-земледельца от наемника, получавшего жалованье ( $\tilde{\eta} \varsigma \mu \iota \sigma \theta о ф о \varrho \tilde{\alpha} \varsigma)$ :

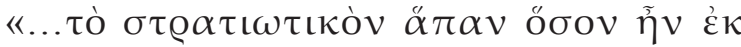

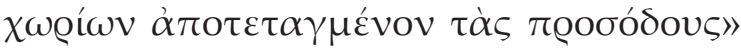

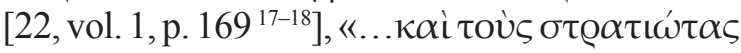

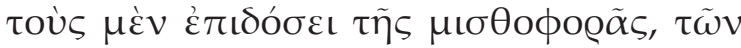

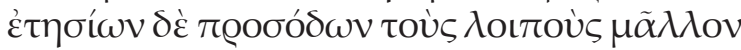

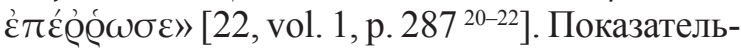
ны также два сообщения Георгия Пахимера о стратиотской службе: организация великим архонтом стратигом Марулисом на востоке империи службы стратиотов, «лишенных лошадей и своих домов, ставших как простые крестьяне» [29, vol. IV, p. $459^{16-19}$ ]; сбор нало-

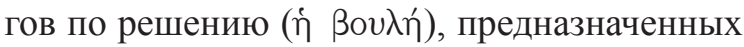
для организации великим примикирием Кассианом выплат стратиотским отрядам Вифинии [29, vol. IV, p. 681 $\left.{ }^{4-7}\right]$.

Как в средневизантийский период, воинские земли раздавались от имени императора отдельным лицам или группам населения. Однако в силу большой численности стратиотских формирований групповые пожалования встречаются чаще. Один из наиболее ярких примеров относится к периоду Никейской империи, в который на основе классических воинских групп в новых условиях экономического и правового развития стали формироваться новые, заложившие основы раннепалеологовских. Речь идет о решении Иоанна III Ватаца касательно введения десяти тысяч куманов в имперские вооруженные силы с соответствующим обеспечением земельными владениями. Очевидно, что первое поколение половцев ассоциировалось современниками с наемниками. Однако условия землячества способствовали интеграции куманов в византийскую социально-экономическую систему. В результате последующие поколения осевших иноземцев воспринимались ромеями исключительно в

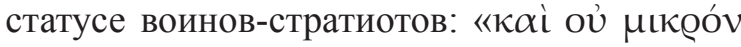

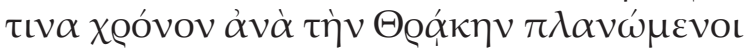
$\pi \varepsilon \varrho ı \eta ́ \varepsilon \sigma \alpha v, \alpha \dot{\alpha} \pi$ oเkí $\alpha v \zeta \eta \tau o \tilde{v} v \tau \varepsilon \varsigma$

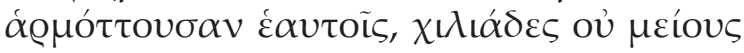




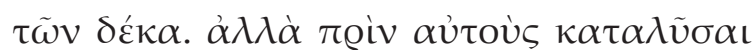

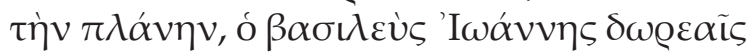

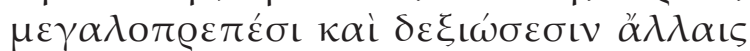

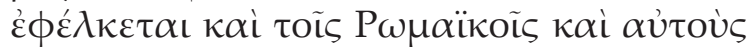

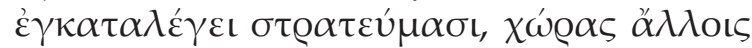

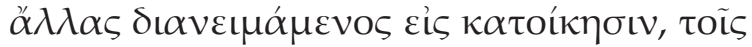

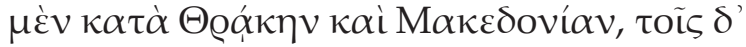

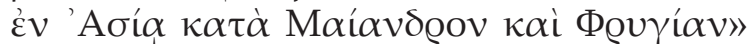
[27, vol. 1, p. $\left.37^{2-9}\right]$.

Возможно, именно в связи с этим первое поколение кочевников определялось в источниках в составе византийской армии как отдельная группа воинов - «скифов». Вместе с тем уже в конце правления Михаила VIII в источниках не фиксируется приведенный этноним (куманы). Очевидно, именно к этому времени и произошла их правовая ассимиляция с категорией ромейского населения - воиновстратиотов. Наше предположение позволяет признать ошибочным мнение П. Мутафчиева о том, что наемники, получивщие земельные участки, априори обретали статус воиновстратиотов [7, с. 9].

Как уже упоминалось, воинские земли раздавались не только ромеям-стратиотам, но и наемникам. Нередко они получали земельные участки как дополнительную к жалованью или как замещающую его форму материального обеспечения. Так, при Михаиле Палеологе лаконцы получили земли в столице $[29$, vol. I, p. $\left.253^{6-10}\right]$; при Андронике II критяне были заселены на малоазийской территории [29, vol. III, p. $235^{27-29}, 237^{1-5}$ ]; наемникам в дополнение к денежной оплате службы передали участки в годы войны между Андроником II и Андроником III [22, vol. 1, p. $164{ }^{22-23 ;}$ 22, vol. 1, p. $167^{7-10}$ ].

В большинстве случаев источником земельных пожалований был императорский домен. Однако при определенных условиях василевсы предпринимали изъятия и распределения между стратиотами частных земель. В частности, в начале XIV в., после захвата турками большей части византийских малоазийских владений, Андроник II попытался именно таким методом исправить ситуацию. Очевидно, Марулис, направленный императором на Восток, должен был не просто нанять на службу анатолийское население, но и создать условия материальной заинтересованности незнатных воинов, простых крестьян- мигрантов. Это определенно было возможно через распределение опустевших земель [29, vol. IV, p. $459^{16-19}$ ].

Таким образом, василевсу удалось не только пополнить ряды византийской армии новоявленными стратиотами, но и, очевидно, повысить моральный дух армии, движимой идеей защиты от противника собственных земель.

Потребность в земельных участках для стратиотов нередко удовлетворялась путем изъятия земель у монастырей, церкви и знати. Согласно актовым материалам василевс получал одобрение на проведение таких мероприятий [21, p. 212].

В период междоусобиц XIV в. распределение конфискованных земель среди стратиотов использовалось как основной механизм материального стимулирования к службе. Так, именно обещание распределения земель, приносящих «доходы в изобилии» («тої $\delta \dot{\varepsilon}$

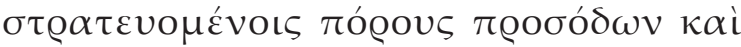
$\mu \iota \sigma \theta \tilde{\omega} \nu \dot{\varepsilon} \pi \iota \delta o ́ \sigma \varepsilon \iota \varsigma »\left[27\right.$, vol. 1, p. $\left.397^{11-12}\right]$ ), позволили Андронику III собрать против деда

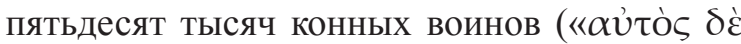

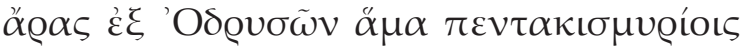

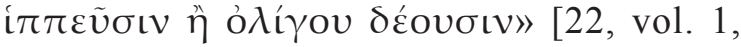
p. $\left.108^{11-13}\right]$ ). Кроме того, заверениями распределить участки между достойными славной службой соратниками изменник Сиргиан смог привлечь на свою сторону многочис-

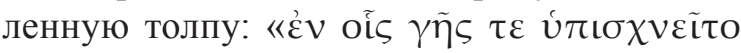

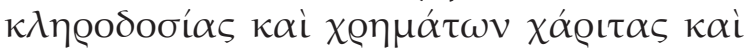

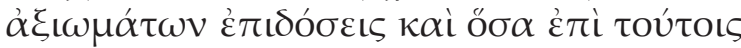

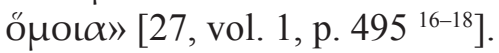

Очевидно, опасаясь предательства, Андроник III начал раздачу земель воинам и военачальникам еще в период военного противостояния Андронику II. По этой причине одним их условий Эпитавтского мира было признание произведенных захватов земли: «тп̃ $\mu \mu \varepsilon ́ v \tau о\llcorner\gamma \tilde{\eta} \varsigma$

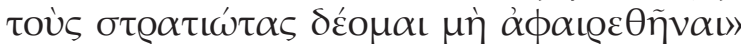
$\left[22\right.$, vol. 1, p. $\left.165^{2-3}\right]$. Эти мероприятия по перераспределению земельных участков явно были направлены не только на покрытие возможных расходов стратиотов в особых условиях внутренней войны. В связи с необходимостью выделение земель могло быть направлено на увеличение численности войск. Основным механизмом решения проблемы выступал перевод земель в статус внесенных в «воинские 


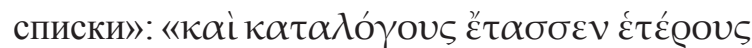

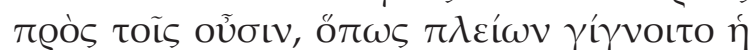

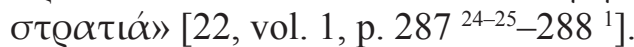

В палеологовский период воинские списки

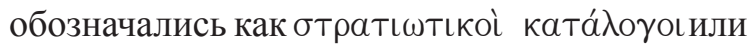

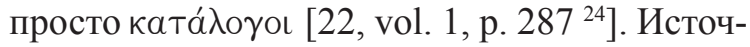
ники указывают на то, что первичным назначением воинских каталогов было определение личного состава, а не только опись имущества.

Безусловно, «запись в войско» означала раздачу земель тем, кто был внесен в каталог. Именно в таких формулировках Никифор Григора описал получение земель куманами. Отметим, что под лицами, записанными на воинскую службу, понимались только воины-

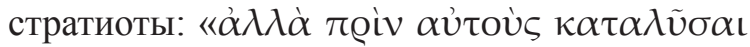

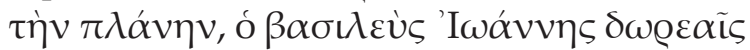

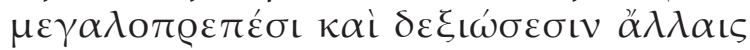

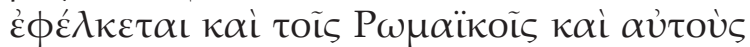

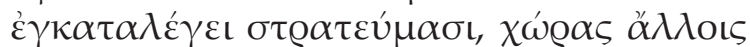

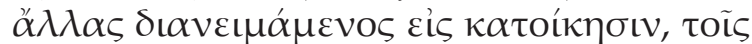

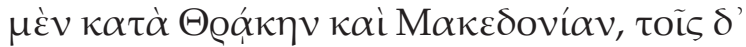

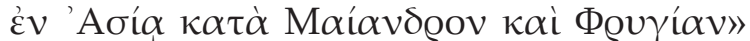
$\left[27\right.$, vol. 1 , p. $\left.37^{4-9}\right]$.

В связи с этим показателен сюжет о снаряжении аланских отрядов Андроником II, распорядившимся снабдить их стратиотским

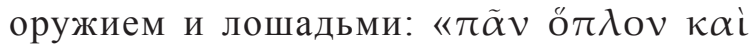

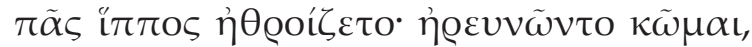

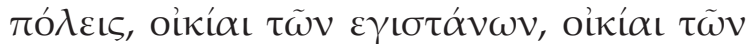

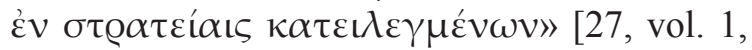
p. $205^{16-18}$ ]. Тот же сюжет присутствует и в сочинении Пахимера. Историк определенно указывает на стратиотов, а не наемников:

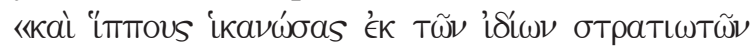

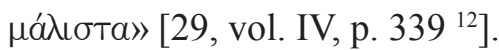

Следуя Иоанну Кантакузину, можно предположить, что группы стратиотов как

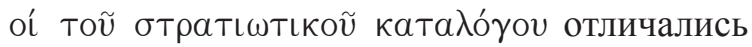
от наемников получением последними жалова-

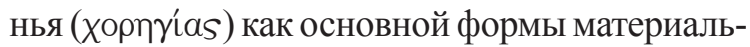

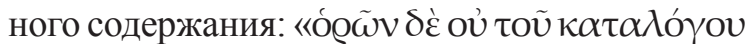

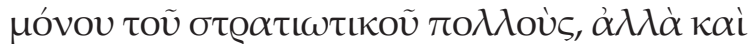

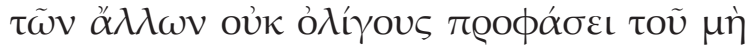
$\tau \dot{\alpha} \varsigma \tau \alpha \varrho \dot{\alpha} \beta \alpha \sigma \iota \lambda \varepsilon \dot{\varepsilon} \omega \varsigma \dot{\varepsilon} \kappa \alpha ́ \sigma \tau \omega \tau \tau \tau \tau \alpha \gamma \mu \varepsilon \dot{v} \alpha \varsigma$

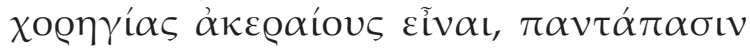

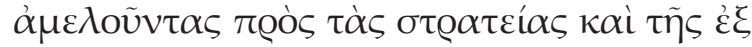

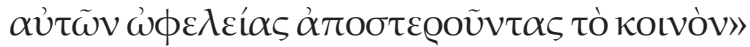
[22, vol. 2, p. $\left.58^{15-19}\right]$.

В поздний период воинская служба как форма публичного обязывания обо-

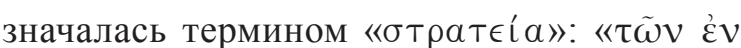
$\sigma \tau \varrho \alpha \tau \varepsilon \dot{\alpha} \alpha\lfloor\varsigma \kappa \alpha \tau \varepsilon \iota \lambda \varepsilon \gamma \mu \varepsilon \dot{v} \nu \omega \nu »$ [27, vol. 1, p. $205^{17-18}$. Это значение встречается и у Кан-

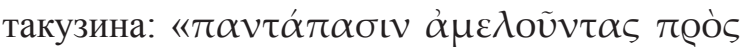

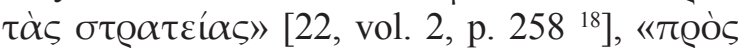

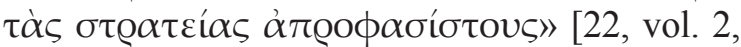
p. $\left.259^{3-4}\right]$. К сожалению, состояние источников не позволяет выделить определенные и конкретные обязанности воинов. Тем не менее мы располагаем обилием общих формулировок. В частности, это относится к известной грамоте Андроника II жителям Янины, в которой сообщается об отрядах воинов, «имеющих икономии и обязанных служить» [20, p. 81].

Учитывая специальный статус воинской службы стратиотов, по окончании боевых действий отряды расформировывали, а воинов отпускали домой. При этом стратиоты как резервисты были готовы к возможности повторного похода [29, vol. I, p. $285^{3}, 295^{13-15}$ ].

Боеспособность вооруженных сил при роспуске стратиотских формирований поддерживалась многочисленными наемниками и изъявившими желание остаться на службе ромеями. Так, например, поступил Канта-

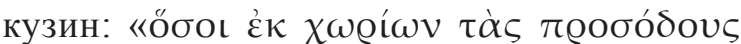

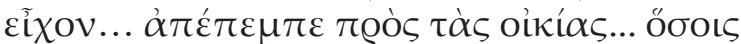

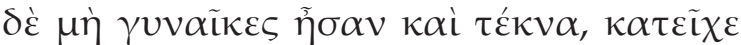

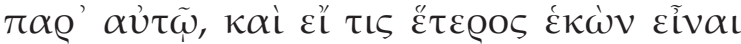

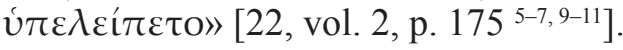

Об объемах поземельных обязательств свидетельствует сообщение Пахимера о приеме на службу многочисленных отрядов алан. Как пишет историк, кроме выданного жалованья, наемники получили лошадей, изъятых у стратиотов, и были обеспечены необходимым вооружением [29, vol. IV, p. $\left.339^{10-21}\right]$. По уточнению Григоры, снаряжение было выделено от воинов, «записанных на военную службу»:

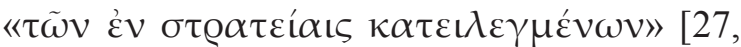
vol. 1, p. $205^{17-18}$ ].

Итак, основу стратиотской службы в мирное время составляла обязанность воинов-стратиотов экипироваться и быть в постоянной боевой готовности. Очевидно, исполнение данной обязанности находилось в прямой зависимости от дохода с земельных

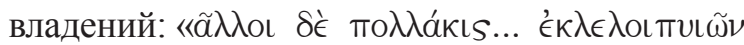

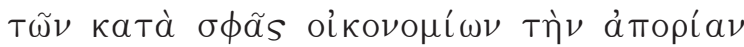

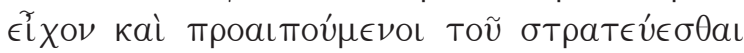

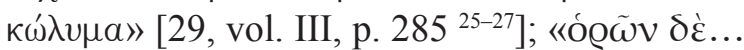




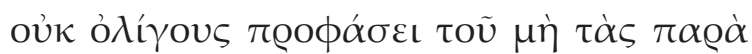

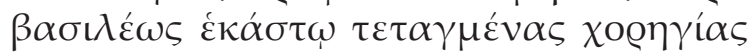

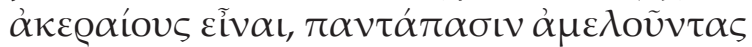

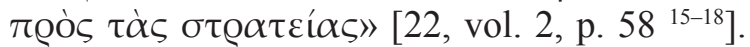

\section{Состав и численность}

\section{провинциального войска}

Безусловно, как и в средневизантийскую эпоху, от стратиота требовалась характерная воинская подготовка, которой он мог достичь в предварительном обуче-

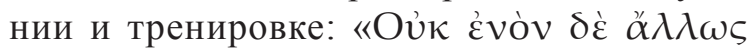

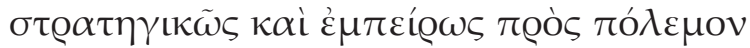

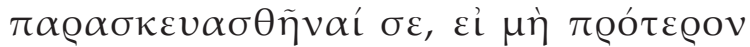

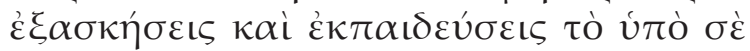

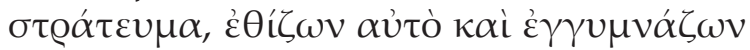

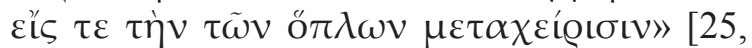
ch. 19 , sec. $3^{1-3}$. При этом целый ряд факторов девальвировал это обязательство.

В поздневизантийский период именно неподготовленность стратиотских войск обусловила непригодность армии и стала одной из причин многочисленных поражений. В связи с этим можно привести множество примеров, когда неопытность и безграмотность в военном искусстве стали причиной разгромов византийских контингентов: войско Мануила Лапардаса в войне против эпирцев

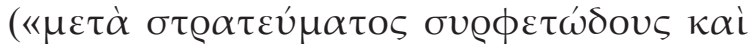
$\xi \hat{\gamma} \gamma \kappa \lambda v \delta о \varsigma »\left[19\right.$, p. $\left.146^{24-25}\right]$ ); поражение пафлагонийских стратиотов в период прав-

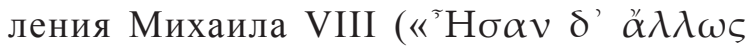

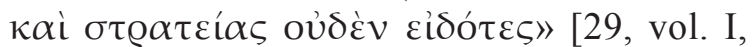
p. $\left.293{ }^{13}\right]$ ); случай с войском Андроника III в походе против Орхана («то̀ $\delta \dot{\varepsilon} \pi \lambda \varepsilon \tilde{\imath} \sigma \tau о \nu$

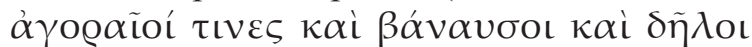

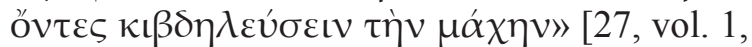
p. $433^{19-21}$.

Показателен в связи с этим случай с лже-Ивайло, под знамена которого с подачи василевса, под эгидой борьбы против турок была собрана «неподготовленная, неорганизованная и невооруженная армия» [29, vol. III, p. $213^{14-19}$. Этот пример показывает, что под воздействием внешних факторов император в частном порядке мог пойти на увеличение численности войск, делая неотвратимым укомплектование армии неподготовленными стратиотами. Специальная роль стратиотских формирований подчеркивается рассредоточением воинского населения во всех провинциях
Византии. Основываясь на данных Пахимера, можно определенно указать, что отряды воинов-стратиотов комплектовались в фемах: Пафлагония, Букеларион, Опсикион, Неокастрон, Фракесион, Анатоликон, Вифиния [29, vol. II, p. $\left.403^{9-16}\right]$. Акрополит, Григора, Кантакузин и Морейская хроника повествуют о сражениях и операциях с участием стратиотов из Македонии $\left[19\right.$, p. $\left.145^{4-5}\right]$, Фессалии

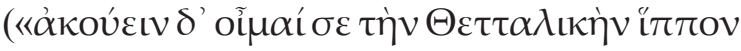

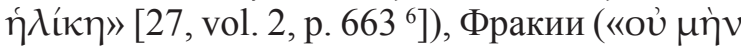

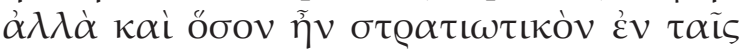

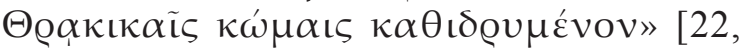

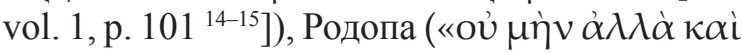

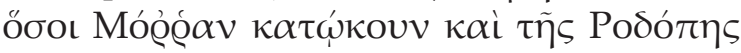

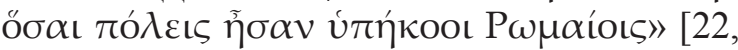
vol. 2, p. $161^{9}$ ]), Велигоста и Скорта [31, p. 330].

Поскольку в редких сообщениях о численности византийской армии учитывался весь состав военнослужащих, определить конкретную численность стратиотов не представляется возможным. Тем не менее на страницах нарративных источников встречаются упоминания о потребности империи в минимальном контингенте на отдельных театрах военных действий.

Прежде всего, стоит отметить цифру в тысячу стратиотов, необходимых для обеспечения защиты Македонии, Фракии и восточных владений. Это количество упомянуто с разницей в четверть века разными авторами [29, vol. IV, p. $5311^{21-22}, 533{ }^{25} ; 27$, vol. 1 , p. $317^{22-23}, 318^{1}$ ].

Основываясь на сообщениях историков о полном боевом обеспечении десяти-шестнадцатитысячного отряда алан за счет ромеевстратиотов («воинов из списков») [29, vol. IV, p. 337-339, 341-345; 27, vol. 1, p. 205], можно предположить, что численность стратиотских формирований как минимум была равной (учитывая наличие двух- и трехлошадных).

Несмотря на такие частные примеры, большинство сообщений источников не позволяют определить численность собственно византийского контингента. В частности, это относится к известному в науке сообщению Пахимера о сорокатысячном войске, отправленному под командованием Иоанна Палеолога на Запад [29, vol. II, p. $\left.421^{3-5}\right]$.

В состав войска могли входить не только ромеи, но и находившиеся на службе импе- 
рии туркопулы и куманы. Численный состав туркопулов можно восстановить по данным относительно их участия в сражениях начала XIV века. Пахимер сообщает лишь о 2000 турецких воинов, пришедших к каталонцам с Востока [29, vol. IV, р. $\left.643^{16-19}\right]$. Исходя из упоминания Григоры о прибытии к каталонцам 500 турок Халила из Малой Азии [27, vol. 1, p. $228^{22-24}$ ], можем предположить, что упомянутые Пахимером турки и составляли отряд Халила. В то же время следует заметить, что в 1308 г., по данным Григоры, в каталонском войске находилось 3000 турок, разделившихся позднее примерно поровну на отряды Мелика и Халила [27, vol. 1, p. $248^{5-6}, 248^{18-23-249^{1-2}}$. Вопрос о численности куманов представляется еще менее определенным ${ }^{2}$.

Самостоятельную категорию между воинами и мирным населением образовывали акриты. Эти группы независимо от стратиотов обеспечивали защиту восточных рубежей империи. На основе ранее проведенных изысканий мы пришли к выводу о том, что в раннепалеологовский период была проведена реформа, в ходе которой акриты были переведены в стратиотское состояние и находились под командованием командиров-прониаров $[2 ; 3 ; 4]$.

Экономически слабые категории военнослужащих, представленные стратиотами - обедневшими крестьянами и акритами, переведенными в статус стратиотов, - были подчинены прониарам. Таким образом обеспечивалась имперская политика по увеличению количества иноземных воинов-наемников за счет снижения затрат на содержание ромейских войск и контингентов, укомплектованных населением империи. Последнее было возможно в результате передачи обязанностей по содержанию рядовых воинов-ромеев прониарам, одной из статей расходов (десять процентов) которых была выплата жалованья стратиотам, в том числе и акритам-стратиотам, приписанным к пожалованным прониям.

Отметим, что хронологическое ограничение сведений об акритах концом XIII в., могло быть прямо связано с перемещением восточных границ империи вследствие турецкой экспансии. Возможно, этот фактор окончательно уравнял в техническом значении акритскую службу со стратиотской. В результате этого формирования пограничников закреплялись за крепостями фем Неокастрон, Фракисион и Опсикион.

\section{К проблеме структуры фемного войска}

Раскрываемая нами концепция фемного войска в поздний период требует внимания к вопросу о системе командования. В связи с этим необходимо остановиться на доктринальном понимании вопроса специфики провинциального управления. С точки зрения военно-политического аспекта темы представляют интерес мнения Э. Арвейлер и Л. Максимовича.

Э. Арвейлер выдвинула идею сохранения фемной военной организации с традиционной структурой [11, р. 127, 137, 163]. При этом, по мнению исследователя, дробление фем на множество малых форм привело к выделению в качестве основной структурной единицы катепанства [11, p. 125-126]. Дука фемы осуществлял военное и гражданское руководство катепанством [11, р. 126-127], опираясь на кастрофилаксов и прокафименов, обеспечивавших безопасность города и командование гарнизоном [11, p. 127].

По мнению Л. Максимовича, фемы как административно-территориальные единицы перестали существовать [6, с. 26-27, 30]. Основной административно-территориальной единицей в империи были катепаникионы во главе с кефалием [6, с. 31, 42, 50], осуществлявшим военные и гражданские функции [6, с. 89]. Кефалию катепаникиона помогал прокафимен [6, с. 103].

Л. Максимович полагал, что к концу $\mathrm{XIV}$ в. должность прокафимена была преобразована в титул [6, с. 105]. При этом кастрофилакс выполнял функции помощника кефалия в управлении городским гарнизоном [6, с. 106]. Провинциальные формирования были представлены аллагией [6, с. 109], подконтрольной чаушу. Пытаясь разграничить компетенцию кастрофилакса и чауша, Л. Максимович без существенных оснований предположил, что чауш командовал провинциальным войском, состоявшим из прониаров [6, с. 109], и не был подчинен кефалию. В то же время кастрофилакс, осуществляя командование гарнизоном, находился в прямом подчинении кефалия [6, с. 109-110]. Возникает вопрос, кому же тогда 
был подчинен чауш? В связи с этим следует указать на предположение, выдвинутое М. Бартусисом и П.И. Жаворонковым. Историки полагают, что в палеологовское время продолжилась тенденция к укрупнению фем, выраженная в создании квазифемной организации - великой аллагии, подконтрольной великому чаушу [14, p. 194-195, 202; 1, с. 63-64].

Обобщая основные положения обозначенных концепций, хотелось бы сделать следующие замечания. Великой аллагией современники называли большое войсковое объединение. Именно такое понимание конкретизируется сообщением Пахимера $\left[29\right.$, vol. II, p. $\left.403^{9-16}\right]$. При этом в одном из пассажей историк упомянул об «аллагиях василевса» [29, vol. IV, p. $\left.407^{16-19}\right]$. Полагаем, такой подход определенно указывает на использование историком термина «аллагия» в его традиционном значении - военный отряд численностью от 50 до 350 воинов ${ }^{3}$.

Важно подчеркнуть, что, если бы функционально должности дуки, кефалия и прокафимена замещались чаушем, а великий чауша командовал бы провинциальными войсками, последние должны были регулярно принимать участие в военных действиях и иметь постоянный состав и численность контингента. Все это, очевидно, должно было отразиться в источниках. Однако мы лишь эпизодически без какой-либо системности встречаем упоминания должности-титула великого чауша и чауша.

Так, из сообщений Пахимера мы узнаем об участии войска великого чауша Хранислава в сражениях с турками [29, vol. IV, p. $\left.469^{6-12}\right]$. Кроме того, по данным этого историка, великий чауша Умпертопул командовал отрядом, участвовавшим в сражении с каталонцами у Апроса [29, vol. IV, p. $593^{4-5}, 599^{16-18}$ ]. Нам не известен состав войск этих полководцев. Однако сообщение Пахимера о командовании Умпертопулом отрядом из двухсот всадников при обороне Визы [29, vol. IV, p. $\left.693^{6-10}\right]$ явно указывает на ошибочность предположений о полномочиях великого чауша, высказанных в литературе. В противном случае можно было бы утверждать, что все фемные формирования составляли отряд такой численностью. В подтверждение нашего предположения можно упомянуть о великом чауше Папиласе, вообще не участвовавшем в военных действиях [29, vol. III, p. 21].

Столь частный характер упоминаний в источниках о великом чауше предположительно можно было бы объяснить двумя основаниями: непосвященностью авторов в вопросы военной организации либо неразвитостью самих институтов чауша и великого чауша и, как следствие, отсутствие тех функций, которые им были присущи в более поздний период. Первое из указанных положений определенно не подтверждается, поскольку авторы источников прекрасно разбирались в системе военно-командного управления. Таким образом, считаем очевидным, что в изучаемый период титул-должность не играл существенной роли в военной организации империи. Кроме того, войско чауша и великого чауша не имело постоянного состава.

Исходя из указанного, можно предположить, что фемная система в раннепалеологовский период в определенной степени сохранила свое традиционное значение в военной организации. Учитывая терминологическую неопределенность, характерную для палеологовской империи, считаем необходимым признать актуальность метода, предложенного Э. Арвейлер, в соответствии с которым с дуками фем следует отождествлять лиц, не упомянутых в соответствующей должности, но чью компетенцию и общие действия можно сопоставить с компетенцией главы фемы [11, p. 138].

Помимо основных провинциальных органов управления, источники содержат упоминания о провинциальных войсковых соединениях, сформированных фемах: Пафлагония, Букеларион, Опсикион, Неокастрон, Фракесион, Анатоликон, Вифиния [29, vol. II, p. $403^{9-16}$ ]. В приведенном сообщении Пахимера упоминаются также и тагмы. В то же время при описании войска Филанфропина историк упоминает о тагматархах и навархах [29, vol. II, p. $401{ }^{20-23}$ ]. Можно предположить, что в последнем случае упомянуты главы воинских формирований городов или фем - кефалии и дуки соответственно.

Более определенную структуру фемного войска представить крайне сложно, прежде всего, ввиду разрозненности сообщений источников и отрывочного характера инфор- 
мации. Тем не менее отдельные указания позволяют нам сделать следующие выводы.

Из используемых нами источников известны лишь три упоминания комитов. В двух случаях Пахимер сообщает о конкретных людях: комите конницы василевса Ходине [29, vol. I, p. $\left.47^{10}\right]$ и комите судна генуэзцев [29, vol. IV, p. $579^{23-28}$. Третье упоминание содержится в пассаже, посвященном характеристике сорокатысячной византийской армии, находившейся под управлением Иоанна Палеолога. В перечне командных должностей вслед за мегистанами, лохагами и тагматархами указаны комиты [29, vol. II, p. $401^{22}$ ]. Сообщения историка о комитах не позволяют конкретизировать их функции и роль. Однако, учитывая систему управления армией Византии XI-XII вв., можно предположить, что комиты традиционно должны были командовать отрядом численностью от двухсот до четырехсот воинов.

Следующими в иерархии были должности среднего и высшего командного звена, представленные лохагами и таксиархами. Сообщения о них встречаются неоднократно и имеют системный характер. Так, по данным Пахимера, лохаги составляли командный состав фемного войска, вошедшего в армию Иоанна Палеолога [29, vol. II, p. $401^{21-23}$. Григора указал, что под началом Ликарио служили «лохаги с отрядами» [27, vol. 1, p. 96]. Описывая тяжелое положение византийцев на востоке, Пахимер сообщает, что малые отряды ромеев во главе с лохагами «отважно сражались с турками» [29, vol. IV, p. $453^{4-9}$ ]. В описании сражения у Апроса Григора подчеркнул, что Михаил IX уговорил лохагов остаться на поле боя [27, vol. 1, p. 231]. Обобщение приведенных данных позволяет предположить, что лохаги возглавляли сотни, заменив кентархов. Кроме того, представляет интерес упоминание Пахимера о том, что в войске Иоанна Палеолога было «много лохагов из мегистан» [29, vol. II, p. $421^{5-7}$ ]. Это сообщение свидетельствует о назначении на должности лохагов знатных ромеев, очевидно из числа прониаров. В связи с этим следует отметить, что Пахимер, характеризуя ромейский или наемный отряд, практически всегда сообщал о присутствии мегистан [29, vol. I, p. $41^{16}, 181^{22-23}, 273^{5-6}$; vol. II, p. $401^{21-23}, 421^{6}, 593^{6-11}$; vol. III, p. $293^{24-30}$; vol. IV, p. $339^{9-11}, 465^{15-16}, 475^{20-22}, 533^{7}, 583^{6}$ ].
Таким образом, можно предположить, что в этих пассажах историк вновь указывал на наличие в конкретном войске сотников-лохагов.

Данные о таксиархах в основном содержатся в сочинении Григоры. Историк говорит о них в пяти пассажах, причем во всех случаях сообщает о таксиархах в связке с лохагами [27, vol. 1, p. $\left.68^{12}, 96^{21}, 264,265,230^{24}-231^{1-3}\right]$, очевидно тем самым подчеркивая их иерархическую взаимосвязь. Численность таксии установить не удается. Тем не менее, учитывая наиболее частое упоминание в источниках отрядов численностью, кратной десяти, можно предположить, что таксия представляла собой часть, в которую входило около тысячи воинов, - хилию, и была приблизительно равна мире. Здесь лишь следует добавить, что численность таксии из-за сокращения фемных формирований была ограничена. Об этом, в частности, свидетельствует сообщение Григоры о том, что Филис Палеолог набрал «небольшое войско с лохагами и таксиархами» [27, vol. 1, p. $\left.264^{6}\right]$.

Подходя к выводу о сохранении армии в прежнем составе из наемников и стратиотских формирований, мы сталкиваемся с вопросом о том, чем можно объяснить возросшую военную мощь Византии в период правления Михаила VIII. Очевидно, что успех византийских войск был обусловлен целым рядом факторов. При этом главную роль сыграла реорганизация военной системы, заключавшаяся в передаче прониарам попечения и командования стратиотским ополчением на востоке.

В этой системе из прониаров формировались местные регулярные отряды, находившиеся в подчинении кефалию или прокафимену. Представленное низшим и средним командным звеном «прониарское войско» на время военных экспедиций и стратегических операций было усилено стратиотскими формированиями. В такой структуре прониары реализовывали командные полномочия над десятками, полусотнями и сотнями.

В рамках военных кампаний войсковые формирования собирались в административном центре, к которому они относились: на востоке - города, далее фемы; на западе - катепаникионы.

В ходе сборов происходило объединение под руководством на первой ступени: восток- 
прокафимена, запад - прокафимена, возможно чауши, упомянутого в источниках в должности сотника - лохага; на второй ступени: под командованием дуки и кефалия соответственно, упомянутых в источниках в должности таксиархов. В соответствии с традиционной структурой командований в крупных кампаниях объединенные фемные формирования должны были выступать под командованием великих доместиков или же протостраторов. Однако известный нам случай применения восточных фемных контингентов на западном направлении в составе объединенной армии [29, vol. II, p. 421] еще раз подчеркивает отсутствие постоянной иерархической системы командных титулов. Вместе с тем, представляя перечень званий, занимаемых командирами различных частей армии («мегистаны, лохаги и тагматархи, комиты и навархи») [29, vol. II, p. $\left.401^{21-23}\right]$, находившейся под общим управлением Иоанна Палеолога, Пахимер определенно сообщает о разделении командования тагмными и фемными войсками на высшем и среднем уровне.

Представленная нами модель структурной реорганизации, очевидно, была связана с изменением в стратегии и тактике византийских войск. Полагаем, что произошедшие перемены имели целью создание новой системы обороны границ, позволявшей реагировать на вражеские вторжения, не дожидаясь приказа из столицы. Так, при нападении местные контингенты собирались в административном центре либо осуществляли оборону конкретных городов без усиления с помощью соседних укрепленных пунктов общей административно-территориальной единицы. Наиболее показательным примером можно считать сражения за Магнезию и Филадельфию, оборона которых осуществлялась силами местных военных формирований [29, vol. IV, p. 463, 469-471, 471-473, 535].

Полагаем, именно местные провинциальные войска несли ответственность и обеспечивали безопасность укрепленных населенных пунктов и городов, являвшихся элементами оборонительной системы. Ее поражение, прорыв линии гарнизонов, разрушение пассивной системы обороны и, как следствие, продвижение войск противника вглубь государства по решению василевсов в наиболее свободные от западных кампаний периоды нейтрализовывались организацией крупных военных операций с последующим выдворением противника за пределы империи.

Результаты. Проведенное исследование позволяет сделать вывод о сохранении в раннепалеологовский период практики комплектования стратиотских формирований в фемах Пафлагония, Букеларион, Опсикион, Неокастрон, Фракесион, Анатоликон, Вифиния. Вместе с тем не представляется возможным установить точную численность контингента стратиотов. Безусловно, причиной этому было, в том числе, практически не прекращавшееся изменение границ империи.

Провинциальные вооруженные силы от начала комплектования до ведения военных действий находились под полным контролем фемной администрации в лице дуки и кефалия. Отсутствие сообщений о малых подразделениях могло быть вызвано изменением их реального значения в боевых построениях. Следует подчеркнуть выявленную тенденцию объединения гражданской и военной функций провинциального управления и назначения на должность глав фем представителей знатных семей, состоявших на реальной военной службе.

\section{ПРИМЕЧАНИЯ}

${ }^{1}$ Минимальный размер владения конного воина должен был стоить четыре литры золота. Воинам императорского флота предоставлялись владения стоимостью 2 литры [23, p. 262].

${ }^{2}$ См.: [10, с. 140-143, 323-325].

${ }^{3} \mathrm{O}$ таком значении аллагии сообщает Ю.А. Кулаковский со ссылкой на «Неизданную Тактику Льва» [5, с. 122, примеч. 1].

\section{СПИСОК ЛИТЕРАТУРЫ}

1. Жаворонков, П. И. Структура и командный состав сухопутных сил Никейской империи : тра-

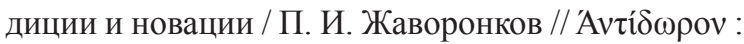
К 75-летию академика РАН Геннадия Григорьевича Литаврина. - СПб. : Алетейя, 2003. - С. 57-65.

2. Золотовский, В. А. К истории византийской армии в XIII в. Реформа акритской службы Михаила VIII Палеолога / В. А. Золотовский // Известия вузов. Северо-Кавказский регион. Общественные науки. - 2009. - № 6. - С. 65-68.

3. Золотовский, В. А. Прония в военной организации Византии раннепалеологовского 
времени. Часть 1 / В. А. Золотовский // Вестник Волгоградского государственного университета. Серия 4, История. Регионоведение. Международные отношения. - 2015. - T. 20, № 3. - C. 100-115. - DOI: http://dx.doi.org/10.15688/jvolsu4.2015.3.10.

4. Золотовский, В. А. Прония в военной организации Византии раннепалеологовского времени. Часть 2 / В. А. Золотовский // Вестник Волгоградского государственного университета. Серия 4, История. Регионоведение. Международные отношения. - 2016. - Т. 21, № 2. - С. 40-51. - DOI: http://dx.doi.org/10.15688/jvolsu4.2016.2.3.

5. Кулаковский, Ю. А. Содержание «Стратегики» / Ю. А. Кулаковский // Стратегика / пер. с среднегреческого и комм. А.К. Нефедкина. - СПб. : Алетейя, 2005. - С. 119-142.

6. Максимовић, Л. Византијска провинцијска управа у доба Палеолога / Л. Максимовић. - Београд : Византолошки институт Српске академије наука и уметности, 1972. - XIX, 199 с.

7. Мутафчиев, П. Войнишки земи и войници в Византия през XIII-XIV в. / П. Мутафчиев // Списание на Българска Академия на науките. 1923. - Вып. 27. - С. 1-113.

8. Сметанин, В. А. О тенденциях идеологической и социальной динамики поздневизантийского общества в период перманентной войны / В. А. Сметанин // Античная древность и средние века. - 1975. Вып. 11. - С. 99-109.

9. Сметанин, В. А. Расходы Византии на армию и флот (1282-1453) / В. А. Сметанин // Античная древность и средние века. - 1975. - Вып. 12. - С. 117-125.

10. Шукуров, Р. М. Тюрки в византийском мире (1204-1461) / Р. М. Шукуров. - М. : Изд-во Московского ун-та, 2017. - 631 с.

11. Ahrweiler, H. L'histoire et la géographie de la région de Smyrne entre les deux occupations turques (1081-1317) particulièrement au XIII-e siecle / H. Ahrweiler // Byzance : les pays et les territories. London : Variorum Reprints, 1976. - P. 1-204.

12. Bartusis, M. C. A Note on Michael VIII's 1272 Prostagma for His Son Andronikos / M. C. Bartusis // Byzantinische Zeitschrift. - 1988. - Bd. 81. S. 268-271.

13. Bartusis, M. C. The Kavallarioi of Byzantium / M. C. Bartusis // Speculum. Journal of Medieval Studies. - 1988. - T. 63. - P. 343-350.

14. Bartusis, M. C. The Megala Allagia and the Tzaousios : Aspects of Provincial Militar Organization in Late Byzantium / M. C. Bartusis // Revue des etudes byzantines. -1989 . - T. 47. - P. 183-207.

15. Bartusis, M. C. On the Problem of Smallholding Soldiers in Late Byzantium / M. C. Bartusis // Dumbarton Oaks Papers. - 1990. - Vol. 44. - P. 1-26.

16. Bartusis, M. C. The Late Byzantine Army : Arms and Society, 1204-1453 / M. C. Bartusis. -
Philadelphia : University of Pennsylvania Press, 1992. - XVII, $438 \mathrm{p}$.

17. Charanis, P. On the Social Structure and Economic Organization of the Byzantine Empire in the Thirteenth and Later / P. Charanis // Byzantinoslavica. 1951. - T. XII, Fasc. 1-2. - P. 94-153.

18. Constantini Harmenopuli Manuale legum, sive, Hexabiblos : cum appendicibis et legibus agrariis / ad fidem antiquorum librorum mss. editionum recensuit, scholiis nondum editis locupletavit, Latinam Reitzii translationem correxit, notis criticis, locis parallelis glossario illustravit Gustav Ernst Heimbach. - Lipsiae : T.O. Weigel, 1851. - XXXII, $1003 \mathrm{p}$.

19. Georges Acropolites. Historia // Georgii Acropolitae. Opera. Vol. 1. Continens Historiam, Breviarium historiae, Theodori Scutariotae Additamenta / rec. A. Heisenberg. - Lipsiae : in aedibus B. G. Teubneri, 1903. - P. 1-198.

20. Imperator Andronicus II. Palaeologus confirmat iura, privilegia, exemptiones et posessiones ecclesiae et civitatis Ioanninorum // Acta et diplomata graeca medii aevi / ed. F. Miklosich, J. Müller. - Vindobonae : C. Gerold, 1887. - T. V. P. $77-84$.

21. Imperator Michaël Palaeologus confirmat monasterio liberam possessionem fundi quatruor iugerum, quem donat coenodio prope metochium Pyrgam // Acta et diplomata graeca medii aevi / ed. F. Miklosich, J. Müller. - Vindobonae : C. Gerold, 1890. - T. VI. - P. 212-214.

22. Ioannes Cantacuzenus. Historiae : in 3 vols. / Ioannes Cantacuzenus. - Bonn : Weber, 1828. Vol. 1. - 560 p. ; 1831. - Vol. 2. - 615 p. ; 1832. Vol. 3. -365 p.

23. Jus graeco-romanum. T. III: Novellae constitutiones imperatorum post Justinianum quae supersunt collatae et ordine chronologico digestae / ed. C.E. Zachariae von Lingenthal. - Lipsiae : T. O. Weigel, 1857. - XXXIV, 749 p.

24. Kyriakidis, S. Warfare in Late Byzantium, 1204-1453 / S. Kyriakidis. - Boston : Brill, 2011.-272 p.

25. Le traité sur la guérilla (De velitatione) de l'empereur Nicéphore Phocas (963-969) / ed. G. Dagron, H. Mihăescu, J.-C. Cheynet. - Paris : Editions du Centre national de la recherche scientifique, 1986. $-358 \mathrm{p}$

26. Miklosich, F. Acta et diplomata graeca medii aevi / F. Miklosich, J. Müller. - Vindobonae, C. Gerold, 1871. - Vol. IV. - 442 p.

27. Nicephorus Gregoras. Historia Romana : in 3 vols. / Nicephorus Gregoras. - Bonn : Weber, 1829. - Vol. 1. - 568 p. ; 1830. - Vol. 2. - P. 571-1146 ; 1855. - Vol. 3. -567 p.

28. Oikonomidès, N. A propos des armées des premiers Paléologues et des compagnies de soldats 
/ N. Oikonomidès // Travaux et Mémoires. - 1981. T. 8. - P. 353-371.

29. Pachymérès Georges. Relationes historiques / Éd. par A. Failler, V. Laurent. - Vol. I : Liv. I-III. Paris : Les belles lettres, 1984. - 325 p. ; Vol. II : Liv. IV-VI. - Paris : Les belles lettres, 1984. - P. 328667 ; Vol. III : Liv. VII-IX. - Paris : Inst. fr. d'ét. byz., 1999. - 305 p. ; Vol. IV : Liv. X-XIII. - Paris : Inst. fr. d'ét. byz., 1999. - P. 306-727.

30. Raybaud, L.-P. Le gouvernement et l'administration centrale de l'Empire byzantin sous les premiers Paléologues (1258-1354) / L.-P. Raybaud. Paris : Sirey, 1968. - 293 p.

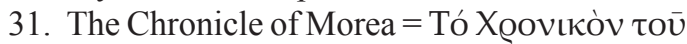

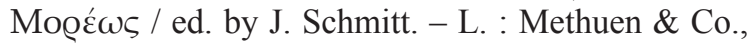
1904. - XCII, $640 \mathrm{p}$.

32. Theodorus Scutariota. Historia. Additamenta ad Georgii Acropolitae historiam // Georgii Acropolitae. Opera. Vol. 1 : Continens Historiam, Breviarium historiae, Theodori Scutariotae Additamenta / rec. A. Heisenberg. - Lipsiae : In aedibus B. G. Teubneri, 1903. - P. 275-302.

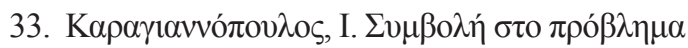

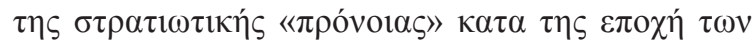

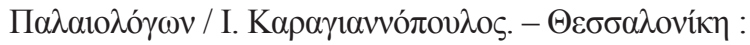

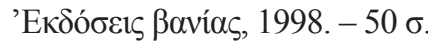

\section{REFERENCES}

1. Zhavoronkov P.I. Struktura i komandnyy sostav sukhoputnykh sil Nikeyskoy imperii: traditsii i novatsii [Structure and Command Staff of Land Forces of the Empire of Nicaea: Traditions and Innovations]. Antidoron: K 75-letiyu akademika RAN Gennadiya Grigorevicha Litavrina [Antidoron: To the $75^{\text {th }}$ Anniversary of Academician of the Russian Academy of Sciences Gennady Grigoryevich Litavrin]. Saint Petersburg, Aleteya Publ., 2003, pp. 57-65.

2. Zolotovskiy V.A. K istorii vizantiyskoy armii v XIII v. Reforma akritskoy sluzhby Mikhaila VIII Paleologa [On the History of the Byzantine Army in the $18^{\text {th }}$ Century. The Reform of Aktites Service of Michael VIII Palaeologus]. Izvestiya vuzov. Severo-Kavkazskiy region. Obshchestvennye nauki [University News. North-Caucasian Region. Social Sciences Series], 2009, no. 6, pp. 65-68.

3. Zolotovskiy V.A. Proniya v voennoy organizatsii Vizantii rannepaleologovskogo vremeni. Chast 1 [Pronoia in the Military Organization of the Byzantine Empire at Early Palaeologian Period. Part 1]. Vestnik Volgogradskogo gosudarstvennogo universiteta. Seriya 4, Istoriya. Regionovedenie. Mezhdunarodnye otnosheniya [Science Journal of VolSU. History. Area Studies. International Relations], 2015, vol. 20, no. 3, pp. 100-115. DOI: http://dx.doi. org/10.15688/jvolsu4.2015.3.10.
4. Zolotovskiy V.A. Proniya v voennoy organizatsii Vizantii rannepaleologovskogo vremeni. Chast 2 [Pronoia in the Military Organization of the Byzantine Empire at Early Palaeologian Period. Part 2]. Vestnik Volgogradskogo gosudarstvennogo universiteta. Seriya 4, Istoriya. Regionovedenie. Mezhdunarodnye otnosheniya [Science Journal of VolSU. History. Area Studies. International Relations], 2016, vol. 21, no. 2, pp. 40-51. DOI: http://dx.doi. org/10.15688/jvolsu4.2016.2.3.

5. Kulakovskiy U.A. Soderzhanie «Strategiki» [Main Ideas of the "Strategika"]. Nefedkina A.K., ed. Strategika. Saint Petersburg, Aleteya Publ., 2005, pp. 119-142.

6. Maksimovih L. Vizantijska provincijska uprava u doba Paleologa [Byzantine Provincial Administration in the Era of Palaeologus]. Beograd, Vizantoloshki institut Srpske akademije nauka i umetnosti, 1972. XIX, 199 p. (in Serbian).

7. Mutafchiev P. Vojnishki zemi i vojnici v Vizantiya prez XIII-XIV v. [Military Lands and Soldiers in the Byzantine Empire During the $18^{\text {th }}-19^{\text {th }}$ Centuries]. Spisanie na Balgarska Akademiya na naukite [Journal of the Bulgarian Academy of Sciences], 1923, iss. 27, pp. 1-113. (in Bulgarian).

8. Smetanin V.A. Otendentsiyakhideologicheskoy i sotsialnoy dinamiki pozdnevizantiyskogo obshchestva $\mathrm{v}$ period permanentnoy voyny [On the Ideological Tendencies and Social Dynamics of Late Byzantine Society in the Period of Permanent War]. Antichnaya drevnost $i$ srednie veka, 1975, iss. 11, pp. 99-109.

9. Smetanin V.A. Raskhody Vizantii na armiyu i flot (1282-1453) [Expenses of the Byzantine Empire on the Army and Navy (1282-1453)]. Antichnaya drevnost i srednie veka, 1975, vol. 12, pp. 117-125.

10. Shukurov R.M. Tyurki v vizantiyskom mire (1204-1461) [Byzantine Turks, 1204-1461]. Moscow, Izd-vo Moskovskogo universiteta, 2017. $631 \mathrm{p}$.

11. Ahrweiler H. L'histoire et la géographie de la région de Smyrne entre les deux occupations turques (1081-1317) particulièrement au XIII-e siecle. Byzance: les pays et les territories. London, Variorum Reprints, 1976, pp. 1-204.

12. Bartusis M.C. A Note on Michael VIII's 1272 Prostagma for His Son Andronikos. Byzantinische Zeitschrift, 1988, vol. 81, pp. 268-271.

13. Bartusis M.C. The Kavallarioi of Byzantium. Speculum. Journal of Medieval Studies, 1988, vol. 63, pp. 343-350.

14. Bartusis M.C. The Megala Allagia and the Tzaousios: Aspects of Provincial Militar Organization in Late Byzantium. Revue des etudes byzantines, 1989, vol. 47, pp. 183-207.

15. Bartusis M.C. On the Problem of Smallholding Soldiers in Late Byzantium. Dumbarton Oaks Papers, 1990, vol. 44, pp. 1-26. 
16. Bartusis M.C. The late Byzantine Army: Arms and Society, 1204-1453. Philadelphia, University of Pennsylvania Press, 1992. XVII, 438 p.

17. Charanis P. On the Social Structure and Economic Organization of the Byzantine Empire in the Thirteenth and Later. Byzantinoslavica, 1951, vol. XII, fasc. 1-2, pp. 94-153.

18. Heimbach G.E., ed. Constantini Harmenopuli Manuale legum, sive, Hexabiblos: cum appendicibis et legibus agrariis. Lipsiae, T.O. Weigel, 1851. XXXII, $1003 \mathrm{p}$.

19. Georges Acropolites. Historia. Heisenberg A., ed. Georgii Acropolitae. Opera. Vol. 1. Continens Historiam, Breviarium historiae, Theodori Scutariotae Additamenta. Lipsiae, in aedibus B.G. Teubneri, 1903, pp. 1-198.

20. Imperator Andronicus II. Palaeologus confirmat iura, privilegia, exemptiones et posessiones ecclesiae et civitatis Ioanninorum. Miklosich F., Müller J., eds. Acta et diplomata graeca medii aevi. Vindobonae, C. Gerold, 1887, vol. V, pp. 77-84.

21. Imperator Michaël Palaeologus confirmat monasterio liberam possessionem fundi quatruor iugerum, quem donat coenodio prope metochium Pyrgam. Miklosich F., Müller J., eds. Acta et diplomata graeca medii aevi. Vindobonae, C. Gerold, 1890, vol. VI, pp. 212-214.

22. Ioannes Cantacuzenus. Historiae: in 3 Vols. Vol. 1. Bonn, Weber, 1828.560 p.; Vol. 2. Bonn, Weber, 1831. 615 p.; Vol. 3. Bonn, Weber, 1832. 365 p.

23. Zachariae von Lingenthal C.E., ed. Jus graeco-romanum. T. III: Novellae constitutiones imperatorum post Justinianum quae supersunt collatae et ordine chronologico digestae. Lipsiae, T.O. Weigel, 1857. XXXIV, 749 p.

24. Kyriakidis S. Warfare in Late Byzantium, 1204-1453. Boston, Brill, 2011. 272 p.

25. Dagron G., Mihăescu H., Cheynet J.-C., eds. Le traité sur la guérilla (De velitatione) de l'empereur
Nicéphore Phocas (963-969). Paris, Editions du Centre national de la recherche scientifique, $1986.358 \mathrm{p}$.

26. Miklosich F., Müller J. Acta et diplomata graeca medii aevi [The Journal of Greek Diplomats and Middle Ages]. Vindobonae, C. Gerold, 1871, vol. IV. 442 p.

27. Nicephorus Gregoras. Schopen L., Bekker I., eds. Historia Romana. In 3 vols. Vol. 1. Bonn, Weber, 1829. 568 p.; Vol. 2. Bonn, Weber, 1830, pp. 571-1146; Vol. 3. Bonn, Weber, 1855. 567 p.

28. Oikonomidès N. A propos des armées des premiers Paléologues et des compagnies de soldats. Travaux et Mémoires, 1981, vol. 8, pp. 353-371.

29. Failler A., Laurent V., eds. Pachymérès Georges. Relationes historiques. Vol. I: Liv. I-III. Paris, Les belles lettres, 1984. 325 p.; Vol. II: Liv. IV-VI. Paris, Les belles lettres, 1984, pp. 328-667; Vol. III: Liv. VII-IX. Paris, Inst. fr. d'ét. byz., 1999. 305 p.; Vol. IV: Liv. X-XIII. Paris, Inst. fr. d'ét. byz., 1999. pp. 306-727.

30. Raybaud, L.-P. Le gouvernement et l'administration centrale de l'Empire byzantin sous les premiers Paléologues (1258-1354). Paris, Sirey, 1968. $293 \mathrm{p}$.

31. Schmitt J., ed. The Chronicle of Morea $=$ To Shronikon tou Moreos [The Chronicle of Morea]. London, Methuen \& Co., 1904. XCII, 640 p. (in Greek).

32. Heisenberg A., ed. Theodorus Scutariota. Historia. Additamenta ad Georgii Acropolitae historiam. Georgii Acropolitae. Opera. Vol. 1: Continens Historiam, Breviarium historiae, Theodori Scutariotae Additamenta. Lipsiae, In aedibus B.G. Teubneri, 1903, pp. 275-302.

33. Karagiannopoylos I. Symbole sto problema tes stratiotikes "pronoias» kata tes epoche ton Palaiologon [Contributing to the Problem of Stratioticle "Pronoia" During the Period of Paleologos]. Thessalonica, editions vania, 1998. 50 p. (in Greek).

\section{Information about the Author}

Vladimir A. Zolotovskiy, Candidate of Sciences (History), Head of the Department of Service and Tourism, Volgograd State University, Prosp. Universitetsky, 100, 400062 Volgograd, Russian Federation, zolotovskiy.azi@volsu.ru, https://orcid.org/0000-0002-4259-8851

\section{Информация об авторе}

Владимир Алексеевич Золотовский, кандидат исторических наук, заведующий кафедрой сервиса и туризма, Волгоградский государственный университет, просп. Университетский, 100, 400062 г. Волгоград, Российская Федерация, zolotovskiy.azi@volsu.ru, https://orcid.org/0000-0002-4259-8851 